\title{
Poverty, Income Inequality, and Growth in Pakistan: A Pooled Regression Analysis
}

\author{
Ahmed Raza Cheema* and Maqbool H. Sial ${ }^{* *}$
}

\begin{abstract}
This study estimates a set of fixed effects/random effects models to ascertain the long-run relationships between poverty, income inequality, and growth using pooled data from eight household income and expenditure surveys conducted between 1992/93 and 2007/08 in Pakistan. The results show that growth and inequality play significant roles in affecting poverty, and that the effect of the former is substantially larger than that of the latter. Furthermore, growth has a significant positive impact on inequality. The results also show that the absolute magnitude of net growth elasticity of poverty is smaller than that of gross growth elasticity of poverty, suggesting that some of the growth effect on poverty is offset by the rise in inequality. The analysis at a regional level shows that both the gross and net growth elasticity of poverty are higher in rural areas than in urban areas, whereas the inequality elasticity of poverty is higher in urban areas than in rural areas. At a policy level, we recommend that, in order to reduce poverty, the government should implement policies focusing on growth as well as adopting strategies geared toward improving income distribution.
\end{abstract}

Keywords: Poverty, inequality, growth, pooled data, Pakistan.

\section{JEL Classification: I32, O40.}

\section{Introduction}

Reducing poverty is a key objective of policymakers, and it has attracted increased attention since the Millennium Development Goals were adopted. Poverty depends on inequality and growth, but the relationships between poverty, income inequality, and growth are not simple. According to Kuznets' hypothesis (1955), inequality initially rises with growth, but then decreases as the benefits of growth trickle down to the poor. Deininger and Squire (1996), Ravallion and Chen (1997), and Dollar and Kraay (2002), however, argue that growth has no impact on inequality. Kaldor (1956), Li and Zou (1998), and Forbes (2000) show that

\footnotetext{
${ }^{*}$ Lecturer in Economics, Department of Economics, University of Sargodha, Pakistan.

${ }^{* *}$ Foreign Faculty Professor, Department of Economics, University of Sargodha, Pakistan.
} 
inequality does lead to growth, but Alesina and Rodrick (1994) demonstrate that inequality affects growth adversely.

In Pakistan, only a few studies have attempted to estimate the longrun relationships between poverty, growth, and income distribution. Ali and Tahir (1999) cover the period 1963/64 to 1993/94 and Saboor (2004) looks only at rural Pakistan for the period 1990/91 to 2001/02. Both use ordinary least squares (OLS) regressions to estimate the relationships between the three variable in question using pooled data from the Household Income and Expenditure Surveys (HIES). The estimation of naïve OLS using pooled data seems problematic, however, since it fails to account for the variations in poverty, inequality, and growth across various regions of Pakistan.

A cursory examination of the data on poverty and inequality [Shown in Appendices 1, 2, and 3 reveals stark variations in the time-series estimates of poverty, Gini coefficients, and mean expenditure per adultequivalent across various provinces and even between rural and urban areas of Pakistan. In reality, these regional differences in the levels of poverty and other social welfare measures reflect an underlying disparity in natural endowments and economic opportunities across various regions of Pakistan. To control and account for such differences, we employ panel data techniques - a fixed effects model and random effects model-to estimate the long-run relationships between poverty, inequality, and growth using pooled data from the Pakistan Bureau of Statistics' HIES conducted during 1992/93 to 2007/08.1

The paper is organized as follows. Section 2 describes the datasets and methodologies employed. The results are presented in Section 3, while Section 4 concludes the paper.

\section{Data and Methodology}

\subsection{Datasets}

This study uses eight household income and expenditure surveys for the survey years 1992/93, 1993/94, 1996/97, 1998/99, 2001/02, $2004 / 05,2005 / 06$, and 2007/08. The sample is representative at the national and provincial level with a rural/urban breakup. The detail of the households covered during the various surveys is given in Table 1.

\footnotetext{
${ }^{1}$ The HIES 2007/08 is the most recent survey available.
} 
Table 1: Households covered across provinces over time in Pakistan

\begin{tabular}{ccccccccc}
\hline & \multicolumn{7}{c}{ Sample size (number of households) } \\
\cline { 2 - 9 } Year & $\mathbf{P r}$ & $\mathbf{P u}$ & $\mathbf{S r}$ & $\mathbf{S u}$ & $\mathbf{N r}$ & $\mathbf{N u}$ & $\mathbf{B r}$ & $\mathbf{B u}$ \\
\hline 1993 & 4,078 & 2,517 & 2,039 & 1,570 & 1,802 & 876 & 1,087 & 623 \\
1994 & 4,034 & 2,508 & 2,046 & 1,579 & 1,815 & 890 & 1,141 & 655 \\
1997 & 3,805 & 2,578 & 2,031 & 1,370 & 1,840 & 841 & 1,138 & 658 \\
1999 & 3,729 & 2,531 & 2,172 & 1,532 & 1,844 & 848 & 1,138 & 658 \\
2002 & 3,768 & 2,542 & 2,173 & 1,533 & 1,825 & 840 & 1,403 & 621 \\
2005 & 3,605 & 2,510 & 1,980 & 1,497 & 1,878 & 1,087 & 1,434 & 713 \\
2006 & 3,890 & 2,788 & 2,104 & 1,664 & 1,899 & 1,049 & 1,310 & 733 \\
2008 & 3,849 & 2,751 & 2,093 & 1,670 & 1,883 & 1,048 & 1,408 & 766 \\
\hline
\end{tabular}

Note: $\mathrm{Pr}=$ rural Punjab, $\mathrm{Pu}=$ urban Punjab, $\mathrm{Sr}=$ rural Sindh, $\mathrm{Su}=$ urban $\mathrm{Sindh}, \mathrm{Nr}=$ rural NWFP, $\mathrm{Nu}=$ urban NWFP, $\mathrm{Br}=$ rural Balochistan, $\mathrm{Bu}=$ urban Balochistan.

Source: Pakistan Bureau of Statistics, Household Income and Expenditure Surveys.

This study uses the poverty, inequality, and growth estimates calculated from these surveys (given in Appendices 1, 2, and 3) to find the long-run relationships between them. A set of descriptive statistics is presented in Table 2.

Table 2: Descriptive statistics

\begin{tabular}{lcrrrr}
\hline Variable & Observations & \multicolumn{1}{c}{ Mean } & Std. dev. & Minimum & Maximum \\
\hline Headcount & 64 & 28.59 & 9.85 & 8.95 & 57.05 \\
Gini & 64 & 26.29 & 5.07 & 18.83 & 37.61 \\
Mean exp & 64 & $1,024.63$ & 204.64 & 694.74 & $1,468.72$ \\
\hline
\end{tabular}

Note: Mean exp. $=$ mean expenditure per adult-equivalent.

Source: Authors' calculations.

\subsection{Methodology}

In order to obtain poverty, inequality, and growth estimates, we employ the same methodology used by Cheema (2010) and Cheema and Sial (2010), i.e., a calorie-based approach that takes expenditure as a welfare indicator to estimate the poverty line with the help of which the headcount ratio is calculated. The headcount index calculates the proportion of the population whose consumption is below the poverty line, $z$, estimated below:

$$
H=q / N
$$


where $H$ is the headcount ratio, $q$ is the number of poor, and $N$ is the size of the population. This is direct and easy to calculate and is the most widely used poverty measure.

We estimate inequality using the Gini coefficient, defined as the ratio of the area between the diagonal and the Lorenz curve to the total area of the half-square in which the curve lies (Todaro \& Smith, 2002) (see Appendix 4). The lower the value of the Gini coefficient, the more equal the distribution of income; the higher the value of the Gini coefficient, the more unequal the distribution of income. A 0 value indicates perfect equality (every person has equal income) and a value of 1 shows perfect inequality (one person has all the income). The Gini coefficient satisfies the four axioms of the Pigou-Dalton transfer principle, ${ }^{2}$ income scale independence, ${ }^{3}$ principle of population, ${ }^{4}$ and anonymity. ${ }^{5}$

Per capita income calculated from estimates of gross national product (GNP) and population are often used as a proxy for growth. However, in order to maintain consistency in our analysis, we estimate mean expenditure per adult-equivalent as an indicator of growth calculated from the sample surveys from which poverty and inequality measures have been estimated.

The methodology employed to estimate the long-run relationships between poverty, inequality, and growth is discussed below.

\subsubsection{Measuring the Relationships between Poverty, Income Inequality, and Growth}

In order to determine the relationships between poverty, income inequality, and growth, Ravallion and Datt (1992) decompose changes in poverty into growth and inequality effects. This decomposition sheds light on the relationships between two surveys. There is a residual in this decomposition. Kakwani (1997), however, separates the exact decomposition of the poverty changes into inequality and growth effects in the sense that there is no residual. This decomposition is also made between two surveys.

\footnotetext{
${ }^{2}$ An income transfer from a person who is poorer to a person who is richer should show a rise (or at least not a fall) in inequality and vice versa.

${ }^{3}$ The inequality measure should be invariant to equal proportional changes.

${ }^{4}$ The inequality measure should be invariant to a replication of the population: If two identical distributions are merged, it should not change the inequality.

${ }^{5}$ The inequality measure is independent of individuals' any characteristics other than their income.
} 
Ali and Tahir (1999) and Saboor (2004) estimate OLS regressions to determine the long-run relationships between these three variables using pooled data on Pakistan. The first study estimates the relationship from 1963/64 to 1993/94, using 14 HIES datasets comprising 28 observations (two observations, i.e., urban and rural from each survey). The second study estimates the same from 1990/91 to 2001/02, including seven HIES datasets using 28 observations (one observation for each of the four provinces in each survey for rural Pakistan).

Ravallion and Chen (1997), Adams (2004), and Ram (2007) estimate OLS regressions to determine the long-run relationship between poverty, income inequality, and growth using cross-country data. The first two studies show that growth plays a key role in reducing poverty; the third shows that the elasticity of poverty with respect to growth is smaller than the elasticity of poverty with respect to inequality. Wodon (1999) and Lombardo (2008) estimate fixed effects and random effects models using pooled data on Bangladesh and Italy, respectively, and find that the growth elasticity of poverty is larger than the inequality elasticity of poverty. Wodon shows that the net growth elasticity of poverty is smaller than the gross elasticity of poverty with reference to growth. Deolalikar (2002) also estimates a fixed effects model using pooled data on Thailand; the study's results reveal that the inequality elasticity of poverty is larger than the growth elasticity of poverty.

Wu, Perloff, and Golan (2006) estimate a random effects model using pooled data for 50 US states for the period 1991 to 1997, to determine the role of taxes, transfers, and welfare programs on income inequality. They show that taxes play a more important role in redistributing income in urban than in rural areas, while transfers and welfare programs are more effective in rural areas than in urban areas. Fosu (2009) estimates a random effects model to find out how inequality affects the impact of income growth on the rate of poverty change in subSaharan Africa (SSA) compared to non-SSA, based on an unbalanced panel of 86 countries over 1977-2004. The study shows that the impact of GDP growth on poverty reduction is a decreasing function of initial inequality. Income growth elasticity is substantially less for SSA. Janjua and Kamal (2011) also estimate a random effects model to examine the impact of growth and education on poverty using a panel dataset for 40 developing countries for the period 1999 to 2007. Their study shows that growth plays a moderately positive role in poverty reduction, but that income distribution did not play a key role in alleviating poverty in the sample overall. The study also shows that the most significant contributor to poverty alleviation was education. 
There are significant differences among the provinces, and even between urban and rural areas in Pakistan. Hence, we apply two panel data techniques: a fixed effects model and a random effects model. First, we estimate a two-way fixed effects model (TWFEM), i.e., across group and over time, and conduct an F-test to find out whether it is applicable. The null hypothesis states that both dummy parameters-group and time-are equal to 0 . The study rejects the hypothesis in favor of the fixed effects model. Next, we estimate a two-way random effects model (TWREM) again, across group and over time-and conduct a Breusch-Pagan LM test to ascertain whether it can be applied. The null hypothesis states that the variance across group and time is equal to 0 . The study rejects the hypothesis in favor of the random effects model.

The Hausman specification test is applied to choose the better of the two models: the TWFEM or the TWREM. The null hypothesis is that the more efficient estimates from the TWREM are also consistent. The study fails to reject the null hypothesis at the 5 percent level of significance, rendering the estimates from the TWREM statistically preferable. However, the TWFEM is also estimated to give further credibility to the empirical results. The models are estimated as follows:

$$
\begin{gathered}
\ln \left(\text { Poverty }_{i t}\right)=\beta_{0}+\beta_{1} \ln \left(\text { Gini }_{i t}\right)+\beta_{2} \ln \left(\text { average expenditure }_{i t}\right)+u_{i}+\gamma_{t}+\varepsilon_{i t} \\
H_{0}: \beta_{1}=\beta_{2}=0 \\
H_{1}: \beta_{1}>0 \& \beta_{2}<0
\end{gathered}
$$

where (i) $i=1 \ldots N$ refers to the cross section of the provinces, (ii) $t=1 \ldots T$

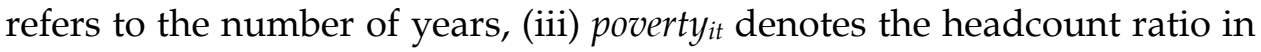
province $i$ in year $t$, (iv) Gini it denotes the Gini coefficient in province $i$ in year $t,(\mathrm{v})$ average expenditure ${ }_{i t}$ denotes the average expenditure in province $i$ in year $t$, (vi) $\mu_{i}$ represents area fixed or random effects, (vii) $\gamma_{t}$ is a time-specific factor, and (viii) $\varepsilon_{i t}$ is an error term such that $\varepsilon_{i t} \sim \operatorname{IID}(0$, $\sigma^{2}$ for all $i$ and $t$ ).

\subsubsection{Measuring the Impact of Growth on Inequality}

During the growth process, inequality may increase or decrease, which in turn affects poverty adversely or favorably. Thus, it is essential to determine the relationship between growth and inequality so that a proper policy can be chalked out if growth is causing inequality to increase. All the relevant tests indicate that the TWFEM is the best model to use. However, as mentioned above, the TWREM is also estimated to check for robustness. 


$$
\begin{gathered}
\ln \left(\text { Gini }_{i t}\right)=\beta_{0}+\beta_{1} \ln \left(\text { Average expenditure }_{i t}\right)+u_{i}+\Upsilon_{t}+\varepsilon_{i t} \\
H_{0}: \beta_{1}=0 \\
H_{1}: \beta_{1} \neq 0
\end{gathered}
$$

All the variables have been defined as discussed above.

\subsubsection{Measuring the Net Impact of Growth on Poverty in Pakistan}

Although the elasticity of poverty with respect to growth is always negative when inequality is fixed, it is possible that inequality may increase or decrease during the growth process. If inequality rises, it will affect poverty adversely and, hence, some of the growth impact on poverty may be lost. However, if inequality declines, it will reinforce the growth impact on poverty and, resultantly, poverty will decrease more than if inequality were to remain unchanged. So, it is essential that we estimate the net growth impact on poverty while allowing inequality to change. In this case, all the relevant tests suggest that a TWREM is the better choice. However, a TWFEM is also estimated to check for robustness.

$$
\begin{aligned}
\ln \left(\text { Poverty }_{i t}\right) & =\beta_{0}+\beta_{1} \ln \left(\text { average expenditure }_{i t}\right)+u_{i}+\gamma_{t}+\varepsilon_{i t} \\
H_{0} & : \beta_{1}=0 \\
H_{1}: & \beta_{1}<0
\end{aligned}
$$

All the variables are explained above. There is, however, another way of estimating the net growth elasticity of poverty:

$\lambda=\gamma+\beta \delta($ Wodon, 1999)

where $\gamma=$ gross elasticity of poverty in terms of headcount ratio with respect to growth while keeping inequality constant, that is, estimated in the model given in Section 2.2.1 ( $\beta_{2}$ in the model); $\beta=$ elasticity of inequality with respect to growth, that is, estimated in the model in Section 2.2.2 ( $\beta_{1}$ in the model); and $\delta=$ elasticity of poverty with respect to inequality while holding growth fixed, that is, estimated in the model given in Section 2.2.1 ( $\beta_{1}$ in the model).

\section{Results and Discussion}

Economic growth helps raise the income of the population, and is, therefore, a necessary condition for poverty reduction, but it is not a sufficient condition. It is possible for inequality to increase during the 
growth process, and if this happens, the poor will benefit less than the nonpoor. If, however, inequality decreases, growth will be pro-poor (Kakwani \& Pernia, 2000). If growth causes inequality to rise sharply, poverty may increase instead of decreasing because the adverse impact of the rising inequality will offset the favorable impact of growth, which implies that the inequality effect dominates the growth effect. Bhagwati (1988) calls this situation "immiserising" growth. Hence, it is instructive to ascertain the separate impact of growth and inequality on poverty.

\subsection{Relationships between Poverty, Inequality, and Growth}

The elasticity of poverty with respect to growth, while holding inequality fixed, is called the gross growth elasticity of poverty; it indicates the percentage change in poverty due to a 1 percent change in mean expenditure, keeping inequality constant. To find the relationship between poverty, inequality, and growth in the long run, all the relevant tests (the results of the F-test, Breusch-Pagan LM test, and Hausman specification test are reported in Appendix 5) indicate that the TWREM is the better choice. Table 3 gives the results of the TWREM; the results of the TWFEM (see Appendix 5) are very similar to those of the TWREM. We apply a series of diagnostic tests to find any autocorrelation and heteroskedasticity, the results of which are also presented in Appendix 5.

Table 3: Relationships between poverty, income inequality, and growth

\begin{tabular}{lccc}
\hline Variables & Pakistan & Rural Pakistan & Urban Pakistan \\
\hline Constant & 16.56 & 21.39 & 10.89 \\
& $(5.82)^{*}$ & $(28.93)$ & $(2.34)^{* *}$ \\
Inequality $(\delta)$ & 0.85 & 0.92 & 1.05 \\
& $(2.05)^{* *}$ & $(6.94)$ & $(2.34)^{* *}$ \\
Growth $(\gamma)$ & -2.33 & -3.07 & -1.63 \\
& $(-4.04)^{*}$ & $(-25.42)$ & $(-2.06)^{* *}$ \\
\hline Diagnostic tests & & & \\
$\begin{array}{l}\text { Autocorrelation } \\
\begin{array}{l}\text { Wooldridge } \\
\text { (p-value) }\end{array}\end{array}$ & 0.44 & 2.17 & 1.16 \\
$\begin{array}{l}\text { Heteroskedasticity } \\
\text { Lr test } \\
\text { (p-value) }\end{array}$ & $(0.53)$ & $(0.24)$ & $(0.36)$ \\
\hline
\end{tabular}

Notes: T-values in parentheses are based on heteroskedasticity-corrected standard error (Arellano, 1987) in case of an indication of heteroskedasticity. ${ }^{*}=$ significant at 0.01 level, ** = significant at 0.05 level. Headcount ratio is a dependent variable. Wooldridge test shows that there is no autocorrelation.

Source: Authors' calculations. 
Table 3 shows that all the coefficients have the expected signs. The results show that growth has a significant, strong negative relationship with poverty, keeping inequality fixed, whereas inequality has a significant positive relationship with poverty, holding growth constant. The results for the gross growth elasticity of poverty reveal that a 1 percent rise in average expenditure while holding inequality fixed decreases the incidence of poverty by 2.33 percent. The table also shows that a 1 percent rise in inequality in expenditure, keeping mean expenditure constant, raises the headcount ratio by 0.85 percent. The results imply that the growth elasticity of poverty is substantially larger than the inequality elasticity of poverty.

The analysis at a rural-urban level shows that the growth elasticity of poverty is higher in rural areas than in urban areas, while the inequality elasticity of poverty is higher in urban areas than in rural areas. The results indicate that a 1 percent increase in mean expenditure reduces poverty by almost 3 percent, holding inequality constant; in urban areas, it decreases poverty by about 1.63 percent. The results for the inequality elasticity of poverty show that a 1 percent increase in inequality increases rural poverty by 0.92 percent, and urban poverty by about 1 percent.

\subsection{Comparison of Results with Other Studies}

Unlike our results for the period 1993/94 to 2007/08, Saboor (2004) shows that the inequality elasticity of poverty dominated the growth elasticity of poverty during 1990/91 to 2001/02 in rural Pakistan. This is because Saboor's study estimates relationships for rural areas during the 1990s, during which the poverty levels we estimated increased in rural Pakistan over the entire period (i.e., 1990/91 and 2001/02) except between 1993/94 and 1995/96. Inequality followed a similar trend over the entire period except between 1990/91 and 1992/93. So, the inequality elasticity of poverty (i.e., 0.31), while holding growth constant, was dominant over the growth elasticity of poverty $(-0.27)$, while keeping inequality fixed, in rural Pakistan.

Our study estimates the relationship between these variables for the 1990s and 2000s for rural, urban, and overall Pakistan. During the latter period, poverty decreased continuously in all three regions. Additionally, although inequality increased during the major part of the period under consideration, there were some periods (i.e., 1993/94 and 1996/97, 1998/99 and 2001/02, 2005/06 and 2007/08) during which inequality decreased. These inequality estimates are consistent with those of the Government of Pakistan (2003). As a result, the growth elasticity of poverty (-3.03), holding 
inequality unchanged, dominated the inequality elasticity of poverty (0.92), keeping growth constant, in rural Pakistan.

Ali and Tahir (1999) show that the inequality elasticity of poverty (1.67) is greater than our results (0.89) at the national level, although both studies show that it is higher in urban areas than in rural areas. The figures given are 1.58 percent in urban areas, and 0.89 percent in rural areas for the period 1963/64 to 1993/94; and 1.05 percent and 0.92 percent in urban and rural areas, respectively, during 1993/94 and 2007/08. The inequality elasticity of poverty (1.67) dominated the growth elasticity of poverty (-0.32) according to Ali and Tahir (1999) during 1963/64 and $1993 / 94$, which is opposite to our results, in which the growth elasticity of poverty $(-2.33)$ is greater than the inequality elasticity of poverty $(0.85)$ estimated for the period 1992/93 to 2007/08.

The reasons are that from 1963-64 up to 19 71-72 there was an increasing trend in poverty. After this, a decreasing trend was observed up to 1984-85. After this, it started to increase again up to 1992-93. As far as inequality is concerned, for the period covered by Ali and Tahir (1999), inequality consistently increased except for the period 1963-64 to 19971-72. As a result, the inequality elasticity of poverty dominated the growth elasticity of poverty.

\subsection{Relationship between Inequality and Growth}

During the growth process, inequality may increase, decrease or remain constant. It is expected to have a positive relationship with poverty. The difference between gross growth and net growth elasticity is due to rising inequality. So, it is instructive to determine the relationship between inequality and economic growth. The results of the TWFEM, which is the statistically preferred model according to the relevant tests (see Appendix 6), are given in Table 4, while the results of the TWREM and diagnostic tests are given in Appendix 6. 
Table 4: Relationship between inequality and growth

\begin{tabular}{lccc}
\hline Variables & Pakistan & Rural Pakistan & Urban Pakistan \\
\hline Constant & 1.97 & 1.81 & 2.04 \\
& $(3.23)^{*}$ & $(1.62)$ & $(2.92)^{*}$ \\
Growth $(\gamma)$ & 0.18 & 0.18 & 0.19 \\
& $(2.06)^{* *}$ & $(1.08)$ & $(1.96)^{* * *}$ \\
\hline Diagnostic tests & & & \\
Autocorrelation & 0.14 & 2.82 & 0.34 \\
$\begin{array}{l}\text { Wooldridge } \\
\text { (p-value) }\end{array}$ & $(0.72)$ & $(0.19)$ & $(0.60)$ \\
$\begin{array}{l}\text { Heteroskedasticity } \\
\text { Lr test } \\
\text { (p-value) }\end{array}$ & 5.73 & & \\
\hline
\end{tabular}

Notes: T-values are given in parentheses. ${ }^{*}, * *$, and ${ }^{* * *}$ denote statistical significance at $0.01,0.05$, and 0.1 levels, respectively. The Gini coefficient is the dependent variable. Wooldridge and $1 \mathrm{r}$ tests indicate that neither autocorrelation nor heteroskedasticity exist. Source: Authors' calculations.

The table shows that an increase in expenditure has a significant positive impact on inequality. A 1 percent rise in average expenditure increases inequality in expenditure by about 0.18 percent. The results for rural areas show that, although the coefficients have the expected signs, they are not statistically significant. Those for urban areas, however, have the expected signs and are also statistically significant at a 0.06 level.

\subsection{Comparison of Results with Other Studies}

Our results are consistent with those of Ali and Tahir (1999) with respect to the variables' signs, but there are differences with regard to magnitude. Our estimated magnitude of growth elasticity of inequality (0.18) for the period 1993/94 and 2007/08 is greater than that of Ali and Tahir for the period between 1963/64 and 1993/94 (0.04). It is possible for growth to have affected inequality more adversely during the period we have considered than that studied by Ali and Tahir.

\subsection{Net Elasticity of Poverty to Growth}

The gross growth elasticity of poverty shows the percentage change in poverty due to a 1 percent change in mean income, keeping inequality fixed. It is quite possible, however, that inequality may increase or decrease during the growth process. Thus, it is essential to estimate the net elasticity 
of poverty to growth, which indicates the percentage change in poverty due to a 1 percent change in mean income. The results of the TWREM, the statistically preferred model according to the relevant tests (see Appendix 7 ), are presented in Table 5. The results of the fixed effects model, which are similar to those of the TWREM, are given in Appendix 7.

The results of the second method (see Section 2.2.3) are presented in Appendix 8, and are consistent with the results estimated by the fixed effects and random effects models.

Table 5: Relationship between poverty and growth

\begin{tabular}{lccc}
\hline Variables & Pakistan & Rural Pakistan & $\begin{array}{c}\text { Urban } \\
\text { Pakistan }\end{array}$ \\
\hline Constant & 16.19 & 22.45 & 12.23 \\
& $(3.49)^{*}$ & $(19.88)^{*}$ & $(2.95)^{*}$ \\
Growth $(\gamma)$ & -1.90 & -2.80 & -1.32 \\
& $(-2.86)^{*}$ & $(-6.82)^{*}$ & $(-2.29)^{* *}$ \\
\hline $\begin{array}{l}\text { Diagnostic tests } \\
\text { Autocorrelation }\end{array}$ & 0.96 & & \\
$\begin{array}{l}\text { Wooldridge } \\
\text { (p-value) }\end{array}$ & $(0.36)$ & 0.03 & 3.95 \\
$\begin{array}{l}\text { Heteroskedasticity } \\
\text { Lr test } \\
\text { (p-value) }\end{array}$ & 46.77 & $(0.87)$ & $(0.14)$ \\
\hline
\end{tabular}

Notes: T-values in parentheses are based on heteroskedasticity-corrected standard error (Arellano, 1987)) in case of an indication of heteroskedasticity. ${ }^{*}=$ significant at 0.01 level, ** = significant at 0.05 level. Headcount ratio is a dependent variable. Wooldridge test shows that there is no autocorrelation.

Source: Authors' calculations.

The table shows that growth has a highly significant negative impact on poverty when we do not control for inequality. A 1 percent increase in average expenditure decreases poverty incidence by 1.88 percent in Pakistan. A comparison of the gross and net growth elasticities of poverty shows that the absolute magnitude of net growth elasticity of poverty $(|-1.88|)$ is smaller than that of the gross growth elasticity of poverty $(|-2.33|)$, implying that some of the effect of growth on poverty is lost due to the rise in inequality.

At the regional level, our analysis shows that the net growth elasticity of poverty is higher in rural areas than in urban areas. The results 
show that a 1 percent increase in mean expenditure decreases rural poverty by 2.80 percent and urban poverty by 1.32 percent.

\subsection{Comparison of Results with Other Studies}

The signs of the coefficients of the present study and Saboor (2004) are consistent, but the magnitude of the coefficient $(-2.80)$ estimated by the present study is greater than that $(-0.25)$ of the latter study. These results of this study are also consistent with those of Ali and Tahir (1999). According to both studies growth elasticity of poverty is greater in rural areas as compared to that in urban areas. But the magnitude of the elasticity $(-1.90)$ at national level is greater in the present study than that $(-0.29)$ of Ali and Tahir (1999) which means that the growth has contributed more to the reduction of poverty during this period (1993-94 and 2007-08) than that period (i.e., 1963-64 and 1993-94).

\section{Conclusion}

This study has estimated a series of TWREMs and TWFEMs to determine the long-run relationship between poverty, income inequality, and growth, using pooled data from eight HIES datasets compiled between 1992/93 and 2007/08 in Pakistan. The results show that growth contributes far more towards reducing poverty, keeping inequality constant, than the latter does to increasing poverty, holding the former constant. The regional-level analyses reveals that the growth elasticity of poverty is higher in rural areas than in urban areas, but that the inequality elasticity of poverty is higher in urban areas than in rural areas.

There is a significant positive relationship between inequality and growth in Pakistan. The results at the rural-urban level show that the growth elasticity of inequality is higher in urban areas than in rural areas. Further, the absolute magnitude of the net elasticity of poverty to growth is smaller than that of the gross elasticity of poverty to growth, implying that some of the growth effect on poverty is offset by the increase in inequality. This is equality valid in rural and urban areas. The net growth elasticity of poverty is higher in rural areas than in urban areas. 


\section{References}

Adams, R. H., Jr. (2004). Economic growth, inequality and poverty: Estimating the growth elasticity of poverty. World Development, 32, 1989-2014.

Alesina, A., \& Rodrik, D. (1994). Distributive policies and economic growth. Quarterly Journal of Economics, 109, 465-490.

Ali, S. S., \& Tahir, S. (1999). Dynamics of growth, poverty and inequality in Pakistan. Pakistan Development Review, 38(4), 337-858.

Bhagwati, J. N., (1988). Poverty and public policy. World Development, 16, 539-654.

Cheema, A. R. (2010). An analysis of relationship among poverty, inequality and growth in Pakistan. Doctoral thesis, Department of Economics, University of Sargodha, Pakistan.

Cheema, A. R., \& Sial M. H. (2010). Estimating the contributions of growth and redistribution to changes in poverty in Pakistan. Pakistan Economic and Social Review, 48(2), 279-306.

Deininger, K., \& Squire, L. (1996). A new data set measuring income inequality. World Bank Economic Review, 10(3), 565-591.

Deolalikar, A. B. (2002). Poverty, growth and inequality in Thailand (Working Paper No. 8). Manila, the Philippines: Asian Development Bank, Economics and Research Department.

Dollar, D., \& Kraay A. (2002). Growth is good for the poor. Journal of Economic Growth, 7, 195-225.

Pakistan Bureau of Statistics. (1994-2009). Household integrated economic survey (HIES). Islamabad, Pakistan: Author.

Forbes, K. (2000). A reassessment of the relationship between inequality and growth. American Economic Review, 90, 869-897.

Fosu, A. K. (2009). Inequality and the impact of growth on poverty: Comparative evidence for sub-Saharan Africa. Journal of Development Studies, 45(5), 726-745. 
Janjua, P. Z., \& Kamal, U.A. (2011). The role of education and income in poverty alleviation: A cross-country analysis. Lahore Journal of Economics, 16(1), 143-172.

Kakwani, N. (1997). On measuring growth and inequality components of poverty with application to Thailand (Discussion paper). Sydney, Australia: University of New South Wales, School of Economics.

Kakwani, N., \& Pernia, E. (2000). What is pro-poor growth? Asian Development Review, 18(1), 1-16.

Kaldor, N. (1956). Alternative theories of distribution. Review of Economic Studies, 23, 83-100.

Kuznets, S. (1955). Economic growth and income inequality. American Economic Review, 45, 1-28.

Li, H., \& Zou, H. (1998). Income inequality is not harmful for growth: Theory and evidence. Review of Development Economics, 2(3), 318334.

Lombardo, V. (2008). Growth and inequality effects on poverty reduction in Italy (Discussion Paper No. 9). Italy: University of Naples, Department of Economic Studies. Retrieved from http:/ / mpra.Ub.uni-muenchen.de/14351/MPRA Paper No.14351 posted 30 .

Park, H. M. (2008). Linear regression models for panel data using SAS, STATA, LIMDEP, and SPSS (Working paper). Bloomington, IN: Indiana University, Center for Statistical and Mathematical Computing.

Ram, R. (2007). Roles of income and equality in poverty reduction: Recent cross-country evidence. Journal of International Development, 19, 919-926.

Ravallion, M., \& Datt, G. (1992). Growth and redistribution components of changes in poverty measures: A decomposition with applications to Brazil and India in the 1980s. Journal of Development Economics, 38, 275-295.

Ravallion, M., \& Chen, S. (1997). What can new survey data tell us about recent changes in distribution and poverty? World Bank Economic Review, 11(2), 357-382. 
Saboor, A. (2004). Agricultural growth, rural poverty and income inequality in Pakistan: A time series analysis. Doctoral thesis, University of Agriculture, Department of Agricultural Economics Faisalabad, Pakistan.

Todaro, M. P., \& Smith, S. C. (2002). Economic development (8 $8^{\text {th }}$ ed.). Reading, MA: Addison-Wesley.

Wodon, Q. T. (1999). Growth, poverty and inequality: A regional panel for Bangladesh (Policy Research Working Paper No. 2072). Washington, DC: World Bank.

Wu, X., Perloff, J. M., \& Golan, A. (2006). Effect of government policies on urban and rural income inequality. Review of Income and Wealth, 52(2), 213-235. 
Appendix 1: Table A1: Headcount ratio across provinces over time in Pakistan

\begin{tabular}{lcccccccc}
\hline Region & $\mathbf{1 9 9 3}$ & $\mathbf{1 9 9 4}$ & $\mathbf{1 9 9 7}$ & $\mathbf{1 9 9 9}$ & $\mathbf{2 0 0 2}$ & $\mathbf{2 0 0 5}$ & $\mathbf{2 0 0 6}$ & $\mathbf{2 0 0 8}$ \\
\hline $\mathrm{Pr}$ & 25.48 & 33.97 & 28.74 & 34.24 & 35.85 & 27.89 & 26.67 & 19.06 \\
$\mathrm{Pu}$ & 21.28 & 18.29 & 17.38 & 23.69 & 23.41 & 16.26 & 12.96 & 10.45 \\
$\mathrm{Sr}$ & 28.64 & 32.14 & 20.20 & 33.13 & 45.02 & 23.87 & 32.20 & 23.02 \\
$\mathrm{Su}$ & 16.68 & 12.19 & 12.10 & 15.09 & 20.01 & 11.14 & 11.11 & 8.95 \\
$\mathrm{Nr}$ & 35.04 & 40.35 & 43.96 & 42.93 & 43.39 & 34.80 & 31.02 & 19.20 \\
$\mathrm{Nu}$ & 24.48 & 26.90 & 28.12 & 25.89 & 29.10 & 22.10 & 24.81 & 13.17 \\
$\mathrm{Br}$ & 26.21 & 38.14 & 43.21 & 20.93 & 37.74 & 28.85 & 57.05 & 55.21 \\
$\mathrm{Bu}$ & 30.43 & 16.96 & 23.26 & 22.78 & 26.18 & 18.78 & 33.74 & 26.87 \\
\hline
\end{tabular}

$\mathrm{Pr}=$ Punjab rural, $\mathrm{Pu}=$ Punjab urban, $\mathrm{Sr}=$ Sindh rural, $\mathrm{Su}=$ Sindh urban, Nr $=$ NWFP rural, $\mathrm{Nu}=$ NWFP urban, $\mathrm{Br}=$ Balochistan rural, $\mathrm{Bu}=$ Balochistan urban .

Appendix 2: Table A2: Gini coefficient across provinces over time in Pakistan

\begin{tabular}{lcccccccc}
\hline Region & $\mathbf{1 9 9 3}$ & $\mathbf{1 9 9 4}$ & $\mathbf{1 9 9 6 / 9 7}$ & $\mathbf{1 9 9 9}$ & $\mathbf{2 0 0 2}$ & $\mathbf{2 0 0 5}$ & $\mathbf{2 0 0 6}$ & $\mathbf{2 0 0 8}$ \\
\hline $\mathrm{Pr}$ & 24.48 & 25.06 & 23.89 & 25.79 & 24.92 & 26.86 & 24.70 & 26.85 \\
$\mathrm{Pu}$ & 32.61 & 31.77 & 29.36 & 37.61 & 31.09 & 34.00 & 35.05 & 31.29 \\
$\mathrm{Sr}$ & 24.82 & 21.75 & 18.88 & 24.76 & 21.81 & 22.18 & 20.73 & 19.65 \\
$\mathrm{Su}$ & 30.63 & 29.46 & 27.97 & 33.50 & 34.65 & 33.83 & 34.24 & 33.83 \\
$\mathrm{Nr}$ & 19.52 & 18.83 & 20.05 & 23.99 & 21.28 & 22.90 & 24.15 & 23.20 \\
$\mathrm{Nu}$ & 29.86 & 29.12 & 26.27 & 35.24 & 27.54 & 32.12 & 33.64 & 32.41 \\
$\mathrm{Br}$ & 19.90 & 20.01 & 19.40 & 22.68 & 19.26 & 21.94 & 23.08 & 19.22 \\
$\mathrm{Bu}$ & 23.37 & 22.48 & 22.89 & 25.84 & 24.36 & 27.51 & 25.51 & 26.71 \\
\hline
\end{tabular}

$\mathrm{Pr}=$ Punjab rural, $\mathrm{Pu}=$ Punjab urban, $\mathrm{Sr}=\mathrm{Sindh}$ rural, $\mathrm{Su}=$ Sindh urban, $\mathrm{Nr}=$ NWFP rural, $\mathrm{Nr}=$ NWFP urban, $\mathrm{Br}=$ Balochistan rural, $\mathrm{Bu}=$ Balochistan urban. 


\section{Appendix 3: Table A3: Mean expenditure per adult-equivalent across provinces over time in Pakistan}

\begin{tabular}{|c|c|c|c|c|c|c|c|c|}
\hline Regio & 1993 & 1994 & 1997 & 1999 & 2002 & 2005 & 2006 & 2008 \\
\hline $\mathrm{r}$ & 9864 & 901.01 & 918.12 & 900.77 & 882.62 & 985.49 & 1,012.16 & $1,116.61$ \\
\hline $\mathrm{Pu}$ & $1,195.58$ & $1,209.28$ & $1,179.67$ & $1,304.30$ & $1,120.30$ & $1,347.58$ & 1,453 & $1,437.19$ \\
\hline$r$ & 37.22 & 863.45 & 921.07 & 887.49 & 766.09 & 39.89 & 55.24 & 913.59 \\
\hline $\mathrm{u}$ & $1,220.54$ & 863.45 & $1,250.94$ & $1,325.89$ & $1,260.13$ & $1,459.72$ & $1,439.44$ & $1,468.72$ \\
\hline $\mathrm{Jr}$ & 8 & & & & 792.90 & 861.38 & 921.18 & $1,017.31$ \\
\hline $\mathrm{Nu}$ & $1,075.18$ & $1,057.52$ & & $1,175.14$ & $1,004.39$ & $1,183.28$ & 1,182.37 & $1,322.61$ \\
\hline , & & & & & & & & 695.05 \\
\hline $3 \mathrm{u}$ & 917.23 & $1,016.13$ & 971.89 & $1,042.67$ & 980.95 & $1,144.91$ & 910.63 & 983.58 \\
\hline
\end{tabular}

$\mathrm{Pr}=$ Punjab rural, $\mathrm{Pu}=$ Punjab urban, $\mathrm{Sr}=\mathrm{Sindh}$ rural, $\mathrm{Su}=$ Sindh urban, Nr = NWFP rural, $\mathrm{Nu}=$ NWFP urban, $\mathrm{Br}=$ Balochistan rural, $\mathrm{Bu}=$ Balochistan urban.

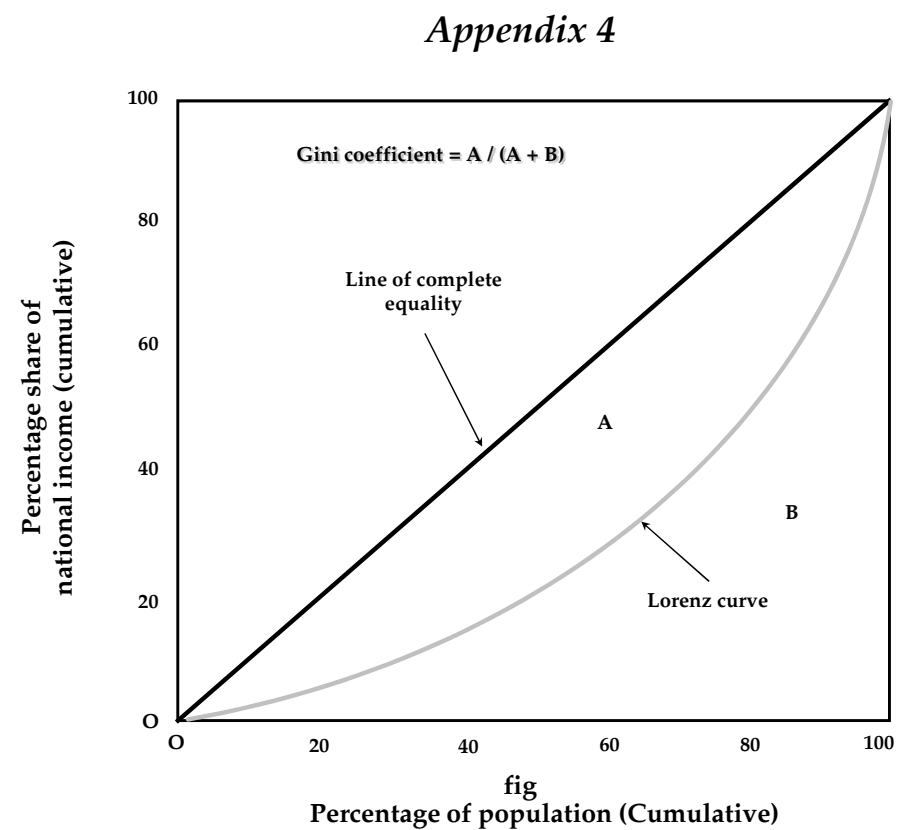




\section{Appendix 5: Table A4: Relationships between poverty, income inequality, and growth}

\begin{tabular}{|c|c|c|c|c|c|c|}
\hline \multirow[b]{2}{*}{ Variables } & \multicolumn{2}{|c|}{ Pakistan } & \multicolumn{2}{|c|}{ Rural Pakistan } & \multicolumn{2}{|c|}{ Urban Pakistan } \\
\hline & $\mathrm{FE}^{\wedge}$ & RE & FE & $\mathrm{RE}^{\wedge}$ & FE & $\mathrm{RE}^{\wedge}$ \\
\hline Constant & $\begin{array}{l}16.56 \\
(5.82)^{*}\end{array}$ & $\begin{array}{l}14.26 \\
(3.25)\end{array}$ & $\begin{array}{l}21.76 \\
(27.85)^{*}\end{array}$ & $\begin{array}{l}21.39 \\
(28.39)^{*}\end{array}$ & $\begin{array}{l}7.15 \\
(1.55)\end{array}$ & $\begin{array}{l}10.89 \\
(2.34)^{* *}\end{array}$ \\
\hline Inequality $(\delta)$ & $\begin{array}{l}0.85 \\
(2.05)^{* *}\end{array}$ & $\begin{array}{l}0.98 \\
(3.88)\end{array}$ & $\begin{array}{l}0.84 \\
(6.05)^{*}\end{array}$ & $\begin{array}{l}0.92 \\
(6.94)^{*}\end{array}$ & $\begin{array}{l}1.63 \\
(4.69)^{*}\end{array}$ & $\begin{array}{l}1.05 \\
(2.34)^{* *}\end{array}$ \\
\hline Growth $(\gamma)$ & $\begin{array}{l}-2.33 \\
(-4.04)^{*}\end{array}$ & $\begin{array}{l}-2.08 \\
(-3.12)\end{array}$ & $\begin{array}{l}-3.09 \\
(-5.42)^{*}\end{array}$ & $\begin{array}{l}-3.07 \\
(-25.22)\end{array}$ & $\begin{array}{l}-1.37 \\
(-1.90)^{* * *}\end{array}$ & $\begin{array}{l}-1.63 \\
(-2.06)^{* *}\end{array}$ \\
\hline $\begin{array}{l}\text { F-test/Breusch- } \\
\text { Pagan LM test } \\
\text { P-value }\end{array}$ & $\begin{array}{l}2.77 \\
(0.00)\end{array}$ & $\begin{array}{l}4.08 \\
(0.04)\end{array}$ & $\begin{array}{l}4.63 \\
(0.01)\end{array}$ & $\begin{array}{l}2.90 \\
(0.09)^{*}\end{array}$ & $\begin{array}{l}5.07 \\
(0.00)\end{array}$ & $\begin{array}{l}6.03 \\
(0.01)\end{array}$ \\
\hline $\begin{array}{l}\text { Hausman } \\
\text { specification test } \\
\text { (p-value) }\end{array}$ & \multicolumn{2}{|c|}{$\begin{array}{c}4.79 \\
(0.09)\end{array}$} & \multicolumn{2}{|c|}{$\begin{array}{c}1.97 \\
(0.37)\end{array}$} & \multicolumn{2}{|c|}{$\begin{array}{c}0.89 \\
(0.35)\end{array}$} \\
\hline \multicolumn{7}{|l|}{ Diagnostic tests } \\
\hline $\begin{array}{l}\text { Autocorrelation } \\
\text { Wooldridge } \\
\text { (p-value) }\end{array}$ & $\begin{array}{l}0.44 \\
(0.53)\end{array}$ & & $\begin{array}{l}2.17 \\
(0.24)\end{array}$ & & $\begin{array}{l}1.16 \\
(0.36)\end{array}$ & \\
\hline $\begin{array}{l}\text { Heteroskedasticity } \\
\text { Lr test } \\
\text { (p-value) }\end{array}$ & $\begin{array}{l}120.91 \\
(0.00)\end{array}$ & & $\begin{array}{l}0.73 \\
(0.99)\end{array}$ & & $\begin{array}{l}49.14 \\
(0.00)\end{array}$ & \\
\hline
\end{tabular}

Notes: T-values in parentheses are based on heteroskedasticity-corrected standard error (Arellano, 1987). ${ }^{*}=$ significant at 0.01 level. $\mathrm{FE}=$ fixed effects model, $\mathrm{RE}=$ random effects model. Headcount ratio is a dependent variable. ${ }^{\wedge}$ denotes preferred model on the basis of statistical tests. 
Appendix 6: Table A5: Relationship between income inequality and growth

\begin{tabular}{|c|c|c|c|c|c|c|}
\hline \multirow[b]{2}{*}{ Variables } & \multicolumn{2}{|c|}{ Pakistan } & \multicolumn{2}{|c|}{ Rural Pakistan } & \multicolumn{2}{|c|}{ Urban Pakistan } \\
\hline & FE & $\mathrm{RE}^{\wedge}$ & $\mathrm{FE}^{\wedge}$ & RE & FE & $\mathrm{RE}^{\wedge}$ \\
\hline Constant & $\begin{array}{c}1.97 \\
(3.23)^{*}\end{array}$ & $\begin{array}{c}0.59 \\
(1.02)\end{array}$ & $\begin{array}{c}1.81 \\
(1.62)\end{array}$ & $\begin{array}{c}0.94 \\
(0.95)\end{array}$ & $\begin{array}{c}2.35 \\
(2.98)^{* *}\end{array}$ & $\begin{array}{c}2.04 \\
(2.92)^{*}\end{array}$ \\
\hline Growth $(\beta)$ & $\begin{array}{c}0.18 \\
(2.06)^{* *}\end{array}$ & $\begin{array}{c}0.39 \\
(4.61)^{*}\end{array}$ & $\begin{array}{c}0.18 \\
(1.08)\end{array}$ & $\begin{array}{c}0.32 \\
(2.16)^{*}\end{array}$ & $\begin{array}{c}0.13 \\
(1.12)\end{array}$ & $\begin{array}{c}0.19 \\
(1.96)^{* * *}\end{array}$ \\
\hline $\begin{array}{l}\text { F-test/Breusch- } \\
\text { Pagan LM test } \\
\text { (P-value) }\end{array}$ & $\begin{array}{c}9.57 \\
(0.00)\end{array}$ & $\begin{array}{c}2.90 \\
(0.09)\end{array}$ & $\begin{array}{c}3.05 \\
(0.02)\end{array}$ & $\begin{array}{c}1.69 \\
(0.19)\end{array}$ & $\begin{array}{c}8.15 \\
(0.00)\end{array}$ & $\begin{array}{c}5.81 \\
(0.02)\end{array}$ \\
\hline $\begin{array}{l}\text { Hausman } \\
\text { specification test } \\
\text { (P-value) }\end{array}$ & \multicolumn{2}{|c|}{$\begin{array}{l}65.57 \\
(0.00)\end{array}$} & \multicolumn{2}{|c|}{$\begin{array}{c}3.42 \\
(0.06)\end{array}$} & \multicolumn{2}{|c|}{$\begin{array}{c}1.45 \\
(0.23)\end{array}$} \\
\hline \multicolumn{7}{|l|}{ Diagnostic tests } \\
\hline $\begin{array}{l}\text { Autocorrelation } \\
\text { Wooldridge } \\
\text { (P-value) }\end{array}$ & \multicolumn{2}{|c|}{$\begin{array}{l}0.137 \\
(0.72)\end{array}$} & \multicolumn{2}{|c|}{$\begin{array}{c}2.82 \\
(0.19)\end{array}$} & \multicolumn{2}{|c|}{$\begin{array}{c}0.34 \\
(0.60)\end{array}$} \\
\hline $\begin{array}{l}\text { Heteroskedasticity } \\
\text { Lr test } \\
\text { (P-value) }\end{array}$ & \multicolumn{2}{|c|}{$\begin{array}{c}5.73 \\
(0.57)\end{array}$} & \multicolumn{2}{|c|}{$\begin{array}{c}1.21 \\
(0.99)\end{array}$} & \multicolumn{2}{|c|}{$\begin{array}{c}3.12 \\
(0.87)\end{array}$} \\
\hline
\end{tabular}

Notes: T-values are given in parentheses. ${ }^{*}=$ significant at 0.01 level. Headcount ratio is a dependent variable. $\mathrm{FE}=$ fixed effects model, $\mathrm{RE}=$ random effects model. ${ }^{\wedge}$ denotes preferred model on the basis of statistical tests. 
Appendix 7: Table A6: Relationship between poverty and growth

\begin{tabular}{|c|c|c|c|c|c|c|}
\hline \multirow[b]{2}{*}{ Variables } & \multicolumn{2}{|c|}{ Pakistan } & \multicolumn{2}{|c|}{ Rural Pakistan } & \multicolumn{2}{|c|}{ Urban Pakistan } \\
\hline & FE & $\mathrm{RE}^{\wedge}$ & FE & $\mathrm{RE}^{\wedge}$ & FE & $R E^{\wedge}$ \\
\hline Constant & $\begin{array}{c}16.19 \\
(3.49)^{*}\end{array}$ & $\begin{array}{c}16.21 \\
(11.81)\end{array}$ & $\begin{array}{c}22.85 \\
(18.26)^{*}\end{array}$ & $\begin{array}{c}22.45 \\
(19.88)^{*}\end{array}$ & $\begin{array}{c}11.00 \\
(2.12)^{* * *}\end{array}$ & $\begin{array}{c}12.23 \\
(2.95)^{*}\end{array}$ \\
\hline Growth $(\beta)$ & $\begin{array}{c}-1.90 \\
(-2.86)^{*}\end{array}$ & $\begin{array}{c}-1.88 \\
(-9.60)\end{array}$ & $\begin{array}{c}-2.88 \\
(-5.56)^{*}\end{array}$ & $\begin{array}{c}-2.80 \\
(-6.82)^{*}\end{array}$ & $\begin{array}{l}-1.16 \\
(-1.57)\end{array}$ & $\begin{array}{c}-1.32 \\
(-2.29)^{* *}\end{array}$ \\
\hline $\begin{array}{l}\text { F-test/Breush- } \\
\text { Pagan LM test } \\
\text { P-value }\end{array}$ & $\begin{array}{c}3.27 \\
(0.00)\end{array}$ & $\begin{array}{c}8.75 \\
(0.00)\end{array}$ & $\begin{array}{c}4.81 \\
(0.00)\end{array}$ & $\begin{array}{l}11.74 \\
(0.00)\end{array}$ & $\begin{array}{l}(4.43) \\
(0.00)\end{array}$ & $\begin{array}{c}6.75 \\
(0.01)\end{array}$ \\
\hline $\begin{array}{l}\text { Hausman } \\
\text { specification test } \\
\text { (P-value) }\end{array}$ & \multicolumn{2}{|c|}{$\begin{array}{c}0.01 \\
(0.92)\end{array}$} & \multicolumn{2}{|c|}{$\begin{array}{c}0.96 \\
(0.33)\end{array}$} & \multicolumn{2}{|c|}{$\begin{array}{c}0.15 \\
(0.70)\end{array}$} \\
\hline \multicolumn{7}{|l|}{ Diagnostic tests } \\
\hline $\begin{array}{l}\text { Autocorrelation } \\
\text { Wooldridge } \\
\text { (p-value) }\end{array}$ & \multicolumn{2}{|c|}{$\begin{array}{c}0.96 \\
(0.36)\end{array}$} & \multicolumn{2}{|c|}{$\begin{array}{l}0.034 \\
(0.87)\end{array}$} & \multicolumn{2}{|c|}{$\begin{array}{c}3.95 \\
(0.14)\end{array}$} \\
\hline $\begin{array}{l}\text { Heteroskedasticity } \\
\text { Lr test } \\
\text { (p-value) }\end{array}$ & \multicolumn{2}{|c|}{$\begin{array}{l}46.77 \\
(0.00)\end{array}$} & \multicolumn{2}{|c|}{$\begin{array}{c}6.47 \\
(0.49)\end{array}$} & \multicolumn{2}{|c|}{$\begin{array}{l}30.48 \\
(0.00)\end{array}$} \\
\hline
\end{tabular}

Notes: T-values in parentheses are based on heteroskedasticity-corrected standard error (Arellano, 1987). ${ }^{*}=$ significant at 0.01 level. Headcount ratio is a dependent variable. $\mathrm{FE}=$ fixed effects model, $\mathrm{RE}=$ random effects model. ${ }^{\wedge}$ denotes preferred model on the basis of statistical tests.

\section{Appendix 8: Table A7: Net growth elasticity of poverty in rural, urban, and overall Pakistan}

\begin{tabular}{|c|c|c|c|}
\hline Variables & Pakistan & Rural Pakistan & Urban Pakistan \\
\hline $\begin{array}{l}\text { Gross growth elasticity } \\
\text { of poverty }(\gamma)\end{array}$ & $\begin{array}{c}-2.33 \\
(-4.04)^{*}\end{array}$ & $\begin{array}{c}-3.07 \\
(-25.42)\end{array}$ & $\begin{array}{c}-1.63 \\
(-4.42)\end{array}$ \\
\hline $\begin{array}{l}\text { Inequality elasticity of } \\
\text { poverty holding growth } \\
\text { constant }(\delta)\end{array}$ & $\begin{array}{c}0.85 \\
(2.05)\end{array}$ & $\begin{array}{c}0.92 \\
(6.94)\end{array}$ & $\begin{array}{c}1.05 \\
(1.93)\end{array}$ \\
\hline $\begin{array}{l}\text { Growth elasticity of } \\
\text { inequality }(\beta)\end{array}$ & $\begin{array}{c}0.18 \\
(2.06)\end{array}$ & $\begin{array}{c}0.18 \\
(1.08)\end{array}$ & $\begin{array}{c}0.19 \\
(1.96)\end{array}$ \\
\hline $\begin{array}{l}\text { Net growth elasticity of } \\
\text { poverty }(\lambda=\gamma+\beta \delta)\end{array}$ & -2.17 & -2.90 & -1.43 \\
\hline
\end{tabular}

Note: ${ }^{*}=$ significant at 0.01 level. 
